Research Article

www.ijrap.net

\title{
NEUROPROTECTIVE EFFECT OF HYDROALCOHOLIC EXTRACT OF ARECA CATECHU LINN ON ß-AMYLOID (25-35) INDUCED COGNITIVE DYSFUNCTION IN MICE
}

R. Kannan*, D. Sivaraman, P. Muralidharan, N. Deepakvenkataraman

Department of Pharmacology and Toxicology, C.L. Baid Metha College of Pharmacy, Chennai, India

Received on: 26/08/13 Revised on: 20/09/13 Accepted on: 17/10/13

\author{
*Corresponding author \\ E-mail: kannanramalingam@yahoo.in \\ DOI: 10.7897/2277-4343.04525 \\ Published by Moksha Publishing House. Website www.mokshaph.com \\ All rights reserved.
}

\section{ABSTRACT}

Alzheimer's disease is the most common form of dementia in elderly. There is currently no cure for Alzheimer's disease. But some category of drugs like AchE inhibitors and NMDA antagonists were used along with some antioxidants and some other supportive therapy. There is a possibility to slow down the brain's degeneration caused by Alzheimer's with natural treatments. In the present study animals were divided randomly into five groups of six animals each. Group I animals were given $0.1 \% \mathrm{w} / \mathrm{v}$ CMC orally by using intra-gastric catheter at dose (10 ml $/ \mathrm{kg})$, Group III and Group IV animals were pretreated with hydroalcoholic extract of Areca catechu Linn (HAEAC) for a period of $3 \mathrm{weeks}(200 \mathrm{and} 400 \mathrm{mg} / \mathrm{kg}$ b.w) and Group V animals were treated with donepezil ( $1.5 \mathrm{mg} / \mathrm{kg} / \mathrm{b}$.w i.p) and were kept in light/dark cycle. During this period the animals were trained in water-maze, Y-maze, exploratory behaviour and passive avoidance apparatus for memory. Amnesia is induced by intra cerebro ventricular injection (I.C.V) of $\beta$ amyloid (25-35). I.C.V injection for the $2^{\text {nd }}, 3^{\text {rd }}, 4^{\text {th }}$ and $5^{\text {th }}$ groups were performed on the $21^{\text {st }}$ day of the pretreated animals and continued for 5 days. The last dose was given 60 minutes prior to behavioral testing and on $30^{\text {th }}$ day scarification of animals was done for in-vitro studies. Hydroalcoholic extract of Areca catechu Linn showed significant protective effect on neurodegeneration and also showed improvement on memory retention activity when compared with $\beta$-amyloid (25-35) induced animals (Group II).

Keywords: Alzheimer's disease (AD), $\beta$-amyloid (25-35), Ubiquitinated proteins, Intra cerebro ventricular injection (I.C.V), Areca catechu Linn.

\section{INTRODUCTION}

Alzheimer's disease (AD) is a progressive neurodegenerative disorder characterized by a gradual decline in memory associated with shrinkage of brain tissue, with localized loss of neurons mainly in the hippocampus and basal forebrain, with diminished level of central cholinergic neurotransmitter-acetylcholine and also reported to be associated with accumulation of ubiquitinated proteins in neuronal inclusions and also with signs of inflammation ${ }^{1}$. Alzheimer's disease is the most prevalent form of dementia which does not have any previous cause such as stroke, brain trauma or alcohol toxicity. It is also distinct from vascular dementia, which is associated with brain infarction. There is a disturbance of higher cortical functions such as memory, speech, learning, thought, orientation and judgment. Consciousness is not affected. The disease is associated with degeneration of cholinergic neurons, particularly those extending from subcortical areas such as nucleus basalis of meynert. There is also a deficit of acetyl choline transferase, the enzyme responsible for the formation of acetyl choline. This results in decreased central cholinergic transmission ${ }^{2}$. Alzheimer's disease affects about $5 \%$ population at the age of $65-80$ years, $10 \%$ between 80 - 95 years and $90 \%$ above 95 years. ${ }^{3}$ Alzheimer disease (AD) is the seventh most prevalent cause of death in the US and the leading cause of dementia, affecting more than 5 million Americans and 26 million worldwide. Without an effective therapy it is estimated that the number of patients with AD will duplicate by the year $2050^{4}$. The fundamental abnormality in $\mathrm{AD}$ is the deposition of $\mathrm{A} \beta$ peptides, which are derived through processing of APP. The A $\beta$ portion of the protein extends from the extracellular region into the transmembrane domain. Processing of APP begins with cleavage in the extracellular domain, followed by an intramembranous cleavage. Once generated, $A \beta$ is highly prone to aggregation-first into small oligomers (which may be the toxic form responsible for neuronal dysfunction), and eventually into large aggregates and fibrils. The $\mathrm{A} \beta$ peptides readily aggregate and can be directly neurotoxic. There are various lines of evidence indicating that the small aggregates of $\mathrm{A} \beta$ can result in synaptic dysfunction, such as blocking of long-term potentiation and changes in other membrane properties. ${ }^{5}$ Areca catechu is the areca palm or areca nut palm betel palm, a species of palm which grows in much of the tropical Pacific, Asia, and parts of east Africa. ${ }^{6}$ The seed of this palm ("areca nut") is used in the preparation of betel quid, generally by combining it with slaked lime and the leaf of Piper betle (betel leaf). Areca palm seed is now among the most important stimulant products in the world used by around 200 to 600 million people globally. ${ }^{7-9}$ The seed contains alkaloids such as arecaidine and arecoline which, when chewed, are intoxicating and slightly addictive. $^{10}$ In this present study the effect of Areca catechu Linn on $\beta$-amyloid induced cognitive dysfunction is studied using mice models.

\section{MATERIALS AND METHODS \\ Collection of plant material}

The plant material was collected from Kerala of India and authenticated at Dept. of Medical Botany, National Institute of Siddha, Chennai, India (Voucher No: NIS/MB/68/2012). 


\section{Preparation of extract}

The nuts of Areca catechu Linn were cleaned and the adherent sand and dust particles were removed. It was dried and made into a coarse powder with the help of electric grinder. About $500 \mathrm{~g}$ of grinded plant material was subjected to Soxhlet extraction $\left(50-60^{\circ} \mathrm{C}\right)$ using hydro alcoholic (water and ethanol in the ratio of 1:1) solvent. The solvent was evaporated at $40^{\circ} \mathrm{C}$ to obtain a viscous mass. The percentage yield of the extract was $20.1 \% \mathrm{w} / \mathrm{w}^{11}$

\section{Animals}

Colony inbred strains of Swiss albino male mice weighing 22-25 g and 2-4 weeks old mice were used in the study. Animals were obtained from C. L. Baid Metha College of Pharmacy which was used for pharmacological studies. The animals were kept under standard conditions at $23-25^{\circ} \mathrm{C}, 12 \mathrm{~h}$. light/dark cycle and given standard pellet diet and water ad libitum. The animals were acclimatized to the laboratory conditions for a week prior to the experiment and randomly divided into four groups of each ten animals. Principles of animal handling were strictly adhered and the handling of animals was made under the supervision of animal ethics committee of this institute. The experimental protocol was approved (Approval. No: IAEC/I/03/CLBMCP/2012 dated 28.08.2012) by Institutional Animal Ethics Committee (IAEC) of CPCSEA (Committee for the Purpose of Control and Supervision of Experimental Animals).

\section{Experimental design}

The animals were divided randomly into five groups of six animals each.

Group I treated with CMC $(0.1 \% \mathrm{w} / \mathrm{v})$

Group II injected with beta amyloid (25-35) $(10 \mu$ i.c.v)

Group III injected with beta amyloid (25-35) (10 $\mu$ l i.c.v)

and treated with $200 \mathrm{mg} / \mathrm{kg}$ of HAEAC (p.o)

Group IV injected with beta amyloid (25-35) (10 $\mu$ l i.c.v) and treated with $400 \mathrm{mg} / \mathrm{kg}$ of HAEAC (p.o)

Group V injected with beta amyloid (25-35) (10 $\mu$ l i.c.v) and treated with donepezil $(1.5 \mathrm{mg} / \mathrm{kg} / \mathrm{b} . \mathrm{w}$ i.p)

Amnesia was induced by intra cerebro-ventricular injection (I.C.V) of beta amyloid. I.C.V injection for the pre treated $2^{\text {nd }}, 3^{\text {rd }}, 4^{\text {th }}$ and $5^{\text {th }}$ groups which was done on the $21^{\text {st }}$ day and was continued for 5 days. Control animals were given $0.1 \% \mathrm{w} / \mathrm{v}$ CMC orally using intra-gastric catheter $(10 \mathrm{ml} / \mathrm{kg})$, where the last dose was given 60 minutes prior to behavioral testing and on $30^{\text {th }}$ day sacrification of animal was done for in-vitro studies.

\section{Assessment of Habituation Behavior Open Field Test (Hole board apparatus)}

Exploratory behavior was evaluated in an open-field paradigm. The open field was made up of plywood and comprises of $40 \times 50 \times 60 \mathrm{~cm}$ dimension. The entire apparatus was painted black and was divided into 16 squares with white lines on the floor. Each animal was placed at one corner of the apparatus and for the next 5 minutes they were observed for their ambulation such as line crossings and head dippings. ${ }^{12}$

\section{Closed Field Activity (Actophotometer)}

The locomotor activity was measured by using an Actophotometer. The actophotometer consists of a square arena $(30 \times 30 \times 25 \mathrm{~cm})$ with wire mesh bottom, in which the animal moves. Six lights and six photocells were placed in the outer periphery of the bottom in such a way that a single mouse can block only one beam. The movement of the animal interrupts a beam of light falling on a photocell, during which a count was recorded and displayed digitally. The locomotor activity was measured for a period of 10 minutes $^{13-14}$.

\section{Assessment of Memory and Retention \\ Passive Shock Avoidance Test}

Passive avoidance behavior based on negative reinforcement was used to examine the long-term memory. The apparatus consists of a box $(27$ X 27 X 27 $\mathrm{cm}$ ) having three walls of wood and one wall of Plexiglas, featuring a grid floor $(3 \mathrm{~mm}$ stainless steel rods set $8 \mathrm{~mm}$ apart) with a wooden platform $(10 \times 7 \times 1.7 \mathrm{~cm})$ in the centre of the grid floor. Electric shock $(20 \mathrm{~V}, \mathrm{AC})$ was delivered to the grid floor. During Training session, each mouse was gently placed on the wooden platform set in the centre of the grid floor, when the mouse stepped down and placed all its paw on the grid floor, shock was delivered for 15 seconds and the Step-Down Latency (SDL) was recorded. SDL is defined as the time taken by the mouse to step down from the wooden platform to grid floor with its entire paw on the grid floor. Animals showing SDL in the range of 2-15 seconds during the first test were used for the second session and the retention test. The second-session was carried out 90 minutes after the first test. During second session, if the animals stepped down before 60 seconds, electric shocks were delivered once again for 15 seconds. During the second test, animals were removed from shock free zone, if they did not step down for a period of 60 seconds and were subjected to retention test. On the $29^{\text {th }}$ day, 90 minutes after the treatment of last dose training was given and memory retention was examined after $24 \mathrm{~h}$ (i.e. on $30^{\text {th }}$ day) in a similar manner, except that the electric shocks were not applied to the grid floor observing an upper cutoff time of 300 seconds. ${ }^{15-16}$

\section{Morris Water Maze Test}

The Morris water maze test is preformed to evaluate spatial working and reference memory. In this model the animals were placed into a large circular pool of water and they can escape onto a hidden platform. The platform is hidden by its placement just below the water surface and by opaque water. Therefore the platform offers no local cues to guide escape behavior. The animal can escape from swimming by climbing onto the platform and with time the animal apparently learns the spatial location of the platform from any starting position at the circumference of the pool. Morris water maze consists of a large circular tank made of black opaque polyvinyl chloride or hard board coated with fiberglass and resin and then surface painted white (1.8-2.0 meter in diameter and 0.4-0.6 meter high). The pool was filled up to a height of $30 \mathrm{~cm}$ with water maintained at around $25^{\circ} \mathrm{C}$ and rendered opaque by addition of a small quantity of milk or 
nontoxic white color. The pool was provided with filling and draining facilities and was mounted at waist level. The tank was hypothetically divided into four equal quadrants and a platform $\left(11 \mathrm{~cm}^{2}\right)$ of $29 \mathrm{~cm}$ height was located in the centre of one of these four quadrants. The platform remains fixed in the position during the training session. Each animal was subjected to four consecutive trials for four days (from $21^{\text {st }}$ to $24^{\text {th }}$ day) during which they were allowed to escape on to the hidden platform and allowed to remain there for 20 seconds. Escape latency time to locate the hidden platform in water maze was noted as an index of acquisition or learning. In case the animal was unable to locate the hidden platform within 120 seconds, it was gently guided by hand to the platform and allowed to remain there for 20 seconds. On the $29^{\text {th }}$ day, 60 minutes after last dose, platform was removed and time spent by each animal in target quadrant searching for the hidden platform was noted as an index of retrieval and measured. $^{17-18}$

\section{Estimation of Brain Neurotransmitters Estimation of Acetylcholineserase enzyme (AchE)}

$20 \mathrm{mg}$ of brain tissue per $\mathrm{ml}$ of phosphate buffer $(\mathrm{pH} 8$, $0.1 \mathrm{~m}$ ) was homogenized in a potter-elvehjem homogenizer. $0.4 \mathrm{ml}$ aliquot of brain homogenate was added to a cuvette containing $2.6 \mathrm{ml}$ of $0.1 \mathrm{~m}$ phosphate buffer ( $\mathrm{pH} 8) .100 \mu \mathrm{l}$ of the DTNB reagent was added to the photo cell. The absorbance was measured at $412 \mathrm{~nm}$ then acetylthiocholine iodide was added. Changes in absorbance were recorded and the change in absorbance per minute was calculated. The enzyme activity is expressed as $\mu$ moles/minute/mg tissue.

\section{Estimation of Mono amino oxidase enzyme (MAO)}

MAO activity was assessed spectrometrically. $250 \mu \mathrm{l}$ solution of the mitochondrial fraction and $100 \mathrm{~mm}$ sodium phosphate buffer ( $\mathrm{pH}$ 7.4) were added up to the final volume of $1 \mathrm{ml}$, the reaction was allowed to proceed at $37^{\circ} \mathrm{C}$ for 20 minutes and stopped by adding $1 \mathrm{~m} \mathrm{HCl}$ $(200 \mu \mathrm{l})$. The reaction product was extracted with $5 \mathrm{ml}$ of butyl acetate, the organic phase was measured at wavelength of $280 \mathrm{~nm}$ in a spectrometer. Blank samples were prepared by adding $1 \mathrm{~m} \mathrm{HCl}(200 \mu \mathrm{l})$ prior to the reaction and worked subsequently in the same manner. ${ }^{19}$

\section{Estimation of Antioxidant Enzyme}

\section{Estimation of super oxide dismutase (SOD)}

The assay mixture should contain $1 \mathrm{ml}$ of pyrogallol-trisDEPTA, $0.2 \mathrm{ml}$ of suitably diluted tissue and $0.8 \mathrm{ml}$ of water. The absorbance was measured at $420 \mathrm{~nm}$. The rate of pyrogallol autoxidation was taken from the increase in absorbance. The activity of SOD was expressed as units/minutes/mg protein. One unit of the enzyme is defined as the amount of enzyme, which inhibits the rate of pyrogallol auto oxidation by $50 \%$. The SOD is expressed as units/min/mg protein. ${ }^{20}$

\section{Estimation of glutathione peroxidase (GPX)}

The reaction mixture consisting of $0.2 \mathrm{ml}$ each of EDTA, sodium azide and $0.4 \mathrm{ml}$ of phosphate buffer, $0.1 \mathrm{ml}$ of suitably diluted tissue was incubated at $37^{\circ} \mathrm{C}$ at different time intervals. The reaction was arrested by the addition of $0.5 \mathrm{ml}$ of TCA and the tubes were centrifuged at 2000 $\mathrm{rpm}$. To $0.5 \mathrm{ml}$ of supernatant, $4 \mathrm{ml}$ of Disodium hydrogen phosphate and $0.5 \mathrm{ml}$ DTNB were added and the color developed was read at $420 \mathrm{~nm}$ immediately. The activity of GPx was expressed as $\mu$ moles of glutathione oxidized/minutes/mg protein. $^{21}$

\section{Estimation of glutathione reductase (GRD)}

The reaction mixture is containing $1 \mathrm{ml}$ of phosphate buffer and $0.5 \mathrm{ml}$ of EDTA. $0.5 \mathrm{ml}$ of oxidized glutathione and $0.2 \mathrm{ml}$ of NADPH was made up to $3 \mathrm{ml}$ with water. After the addition of suitably diluted tissue, the change in optical density at $340 \mathrm{~nm}$ was monitored for 2 minutes at 30 seconds intervals. The activity of GRD was expressed as nmoles of NADPH oxidized/minute/mg protein. $^{22}$

\section{RESULTS}

\section{Effect of HAEAC on Open field activity}

The Group II animals showed significant decrease in head dippings and line crossings when compared with the Group I animals $(\mathrm{p}<0.001)$. Treatment with HAEAC (200 and $400 \mathrm{mg} / \mathrm{kg}$ ) and standard drug Donepezil 1.5 $\mathrm{mg} / \mathrm{kg}$ (i.p) increased the head dippings and line crossings which were statistically significant $(\mathrm{p}<0.01, \mathrm{p}<0.001$ and $\mathrm{p}<0.01$ for Group III, IV and V respectively) when compared with Group II. Results are plotted in histogram1 .

\section{Effect of HAEAC on Closed field activity}

There was a significant $(p<0.001)$ decrease in the activity scores produced by Group II animals when compared with Group I animals. Treatment with HAEAC (200 and $400 \mathrm{mg} / \mathrm{kg}$ ) and standard drug Donepezil 1.5 $\mathrm{mg} / \mathrm{kg}$ (i.p) showed significant $(\mathrm{p}<0.001, \mathrm{p}<0.001$ and $\mathrm{p}<0.001$ for Group III, IV and V respectively) increase in the activity scores when compared with group II animals. Results are plotted in histogram -2 .

\section{Effect of HAEAC on Step down Passive Shock avoidance test}

The Step down Latency (SDL) of Group II animals were significantly decreased $(\mathrm{p}<0.001)$ when compared with Group I animals. Treatment with HAEAC (200 and 400 $\mathrm{mg} / \mathrm{kg}$ ) and standard drug Donepezil $1.5 \mathrm{mg} / \mathrm{kg}$ (i.p) (p < $0.001, p<0.001$ and $p<0.001$ for Group III, IV and V respectively) showed significant increase in the step down latency when compared with Group II. The increase in SDL indicates enhancement in short term memory (STM). Results are plotted in histogram -3 .

\section{Effect of HAEAC on Morris water maze task}

The escape latency of Group II animals was significantly increased when compared with Group I animals ( $\mathrm{p}<$ 0.001). Treatment with HAEAC (200 and $400 \mathrm{mg} / \mathrm{kg}$ ) and standard drug Donepezil $1.5 \mathrm{mg} / \mathrm{kg}$ (i.p) significantly decreased $(\mathrm{p}<0.001, \mathrm{p}<0.001$ and $\mathrm{p}<0.05$ for Group III, IV and V respectively) the escape latency, when compared with the Group II animals. The decrease in escape latency indicates enhancement of memory retention and non-spatial working memory. Results are plotted in histogram -4 . 

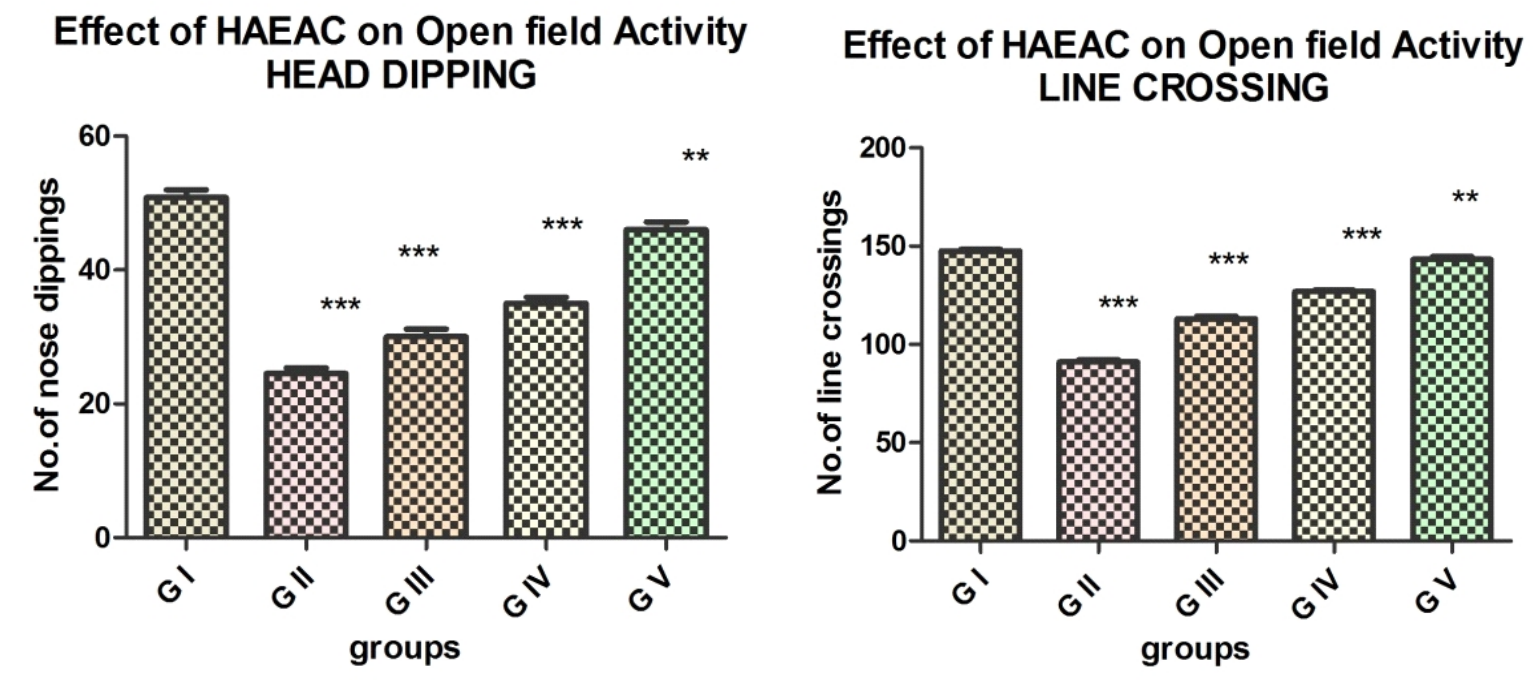

Histogram 1: Effect of HAEAC on Open field Activity

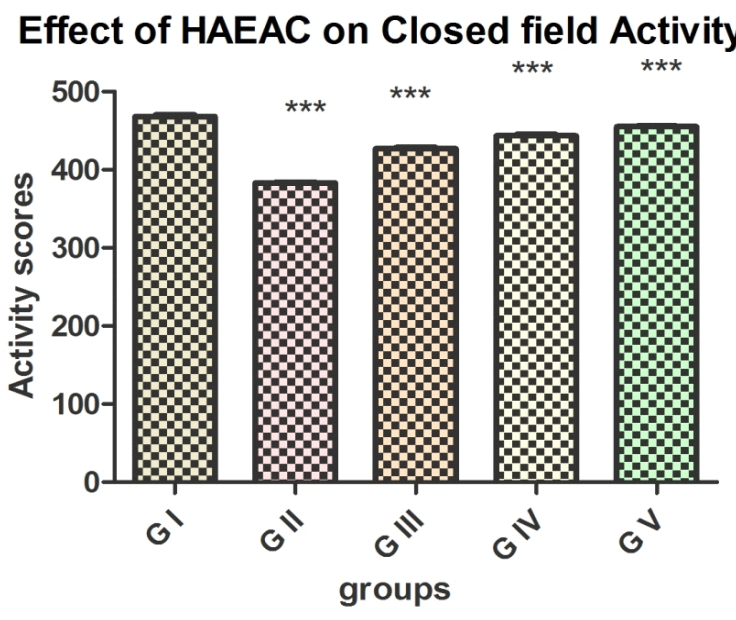

Histogram 2: Effect of HAEAC on Closed field Activity

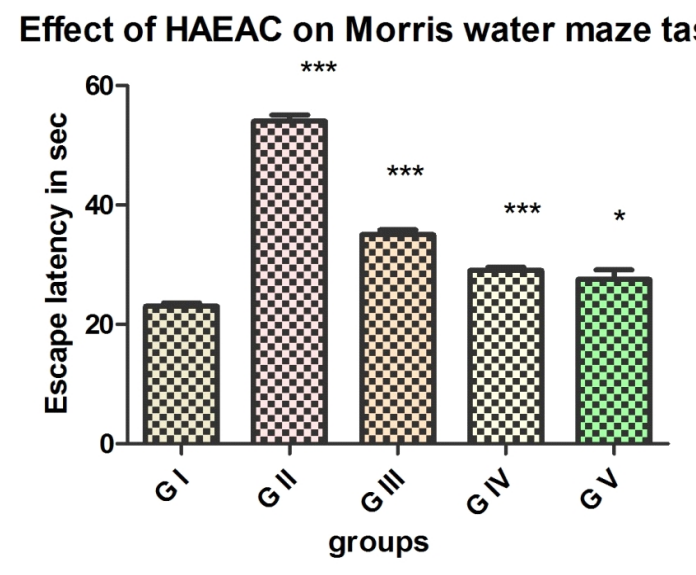

Histogram 4: Effect of HAEAC on Morris water maze task
Effect of HAEAC on Step down Passive Shock avoidance test

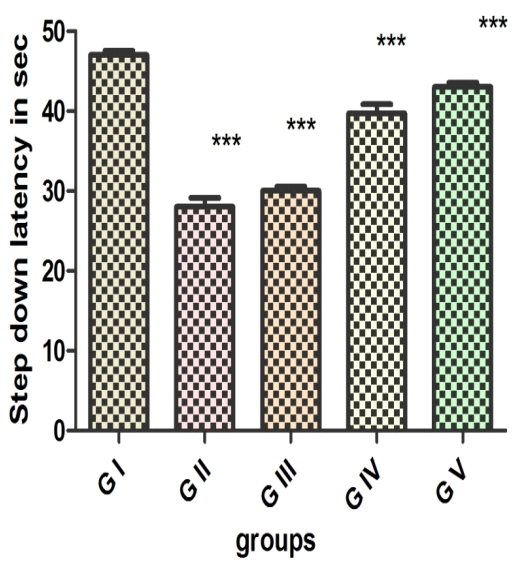

Histogram 3: Effect of HAEAC on Step down Passive Shock avoidance test

\section{Effect of HAEAC on AChE Activity}

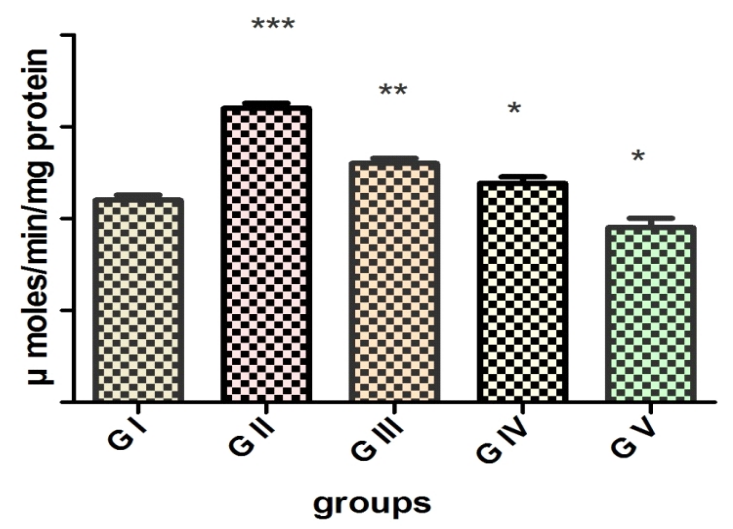

Histogram 5: Effect of HAEAC on AChE Activity 
Effect of HAEAC on Mono amine oxidase A

Effect of HAEAC on Mono amine oxidase B
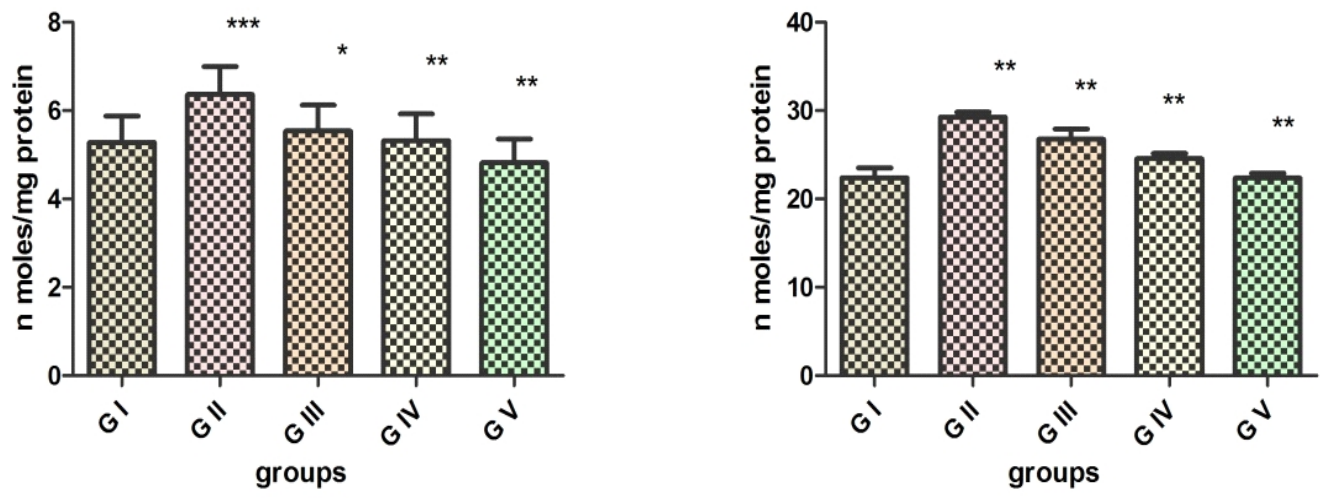

Histogram 6: Effect of HAEAC on MAO-A and MAO-B

Effect of HAEAC on Superoxide dismutase (SOD)

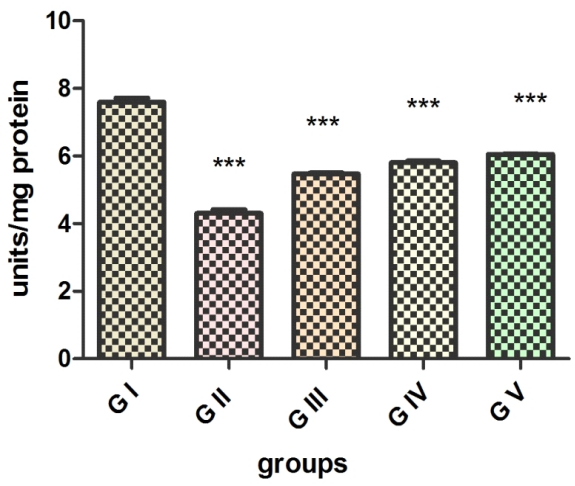

Histogram 7: Effect of HAEAC on Superoxide dismutase (SOD)
Effect of HAEAC on Glutathione peroxidase (GPx)

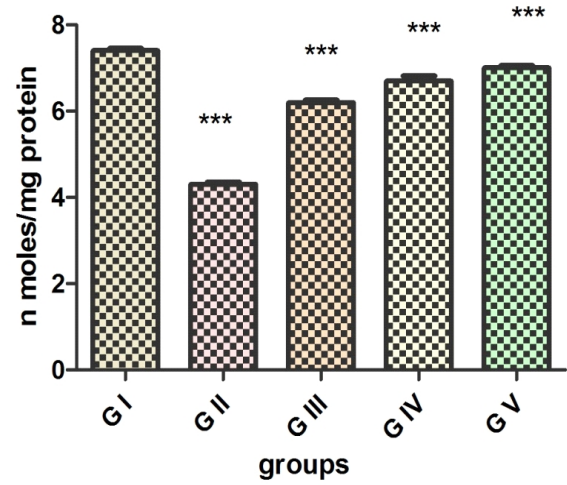

Histogram 8: Effect of HAEAC on Glutathione peroxidase (Gpx)

Effect of HAEAC on Glutathione reductase (GRD)

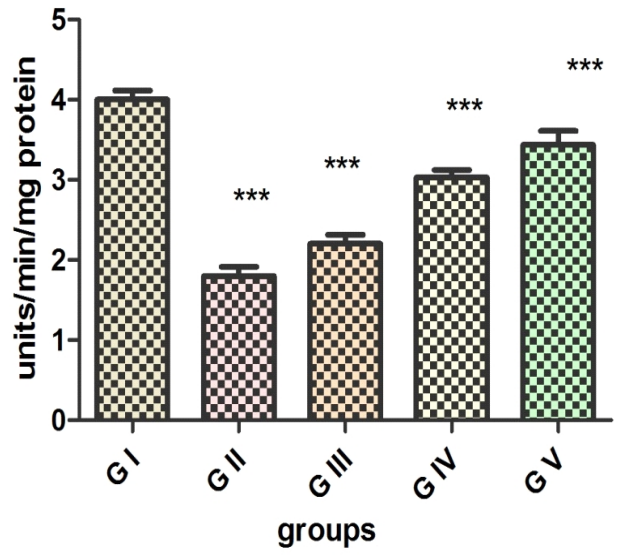

Histogram 9: Effect of HAEAC on Glutathione reductase (GRD) 
Effect of HAEAC on Acetyl cholinesterase level

The level of AchE in group II animals showed $(p<0.001)$ significant increase when compared with Group I animals. Treatment with HAEAC significantly decreased $(\mathrm{p}<0.01$ and $\mathrm{p}<0.01$ for Group III and Group IV $-200 \mathrm{mg} / \mathrm{kg}$ and $400 \mathrm{mg} / \mathrm{kg}$ respectively) the AchE level when compared with Group II animals. Standard drug Donepezil 1.5 $\mathrm{mg} / \mathrm{kg}$ (i.p) (Group V, $\mathrm{p}<0.05)$ showed significant reduction in AchE activity; when compared with Group II animals. Results are plotted in histogram -5 .

\section{Effect of HAEAC on Mono Amine Oxidase A and B}

The level of MAO in group II animals was $(\mathrm{p}<0.001)$ significantly increased when compared with Group I animals. Treatment with HAEAC $200 \mathrm{mg} / \mathrm{kg}$ significantly $(\mathrm{p}<0.05)$ decreased MAO level when compared with Group II animals. Treatment with HAEAC $400 \mathrm{mg} / \mathrm{kg}$ and Donepezil $1.5 \mathrm{mg} / \mathrm{kg}$ significantly $(\mathrm{p}<0.01)$ decreased the MAO level compared with Group II animals. Results are plotted in histogram -6 .

\section{Effect of HAEAC on Superoxide dismutase}

The SOD in the brain of Group II animals were decreased significantly $(\mathrm{P}<0.001)$ when compared with Group I animals. Treatment with HAEAC (200 and $400 \mathrm{mg} / \mathrm{kg}$ ) and standard drug Donepezil $1.5 \mathrm{mg} / \mathrm{kg}$ (i.p) (Group III, $\mathrm{IV}$ and $\mathrm{V}$ respectively) showed significant $(\mathrm{p}<0.001, \mathrm{p}<$ 0.001 and $\mathrm{p}<0.001$ for Group III, IV and V respectively) increase of SOD level when compared with Group II animals. Results are plotted in histogram -7 .

\section{Effect of HAEAC on Glutathione peroxidase}

The Glutathione peroxidase in the brain of Group II animals were decreased significantly $(\mathrm{P}<0.001)$ when compared with Group I animals. Treatment with HAEAC (200 and $400 \mathrm{mg} / \mathrm{kg}$ ) and standard drug Donepezil 1.5 $\mathrm{mg} / \mathrm{kg}$ (i.p) (Group III, IV and V respectively) showed significant $(\mathrm{p}<0.001, \mathrm{p}<0.001$ and $\mathrm{p}<0.001$ for Group III, IV and $\mathrm{V}$ respectively) increase of Glutathione peroxidase level when compared with Group II animals. Results are plotted in histogram -8 .

\section{Effect of HAEAC on Glutathione reductase}

The Glutathione reductase in the brain of Group II animals were decreased significantly $(\mathrm{P}<0.001)$ when compared with Group I animals. Treatment with HAEAC (200 and $400 \mathrm{mg} / \mathrm{kg}$ ) and standard drug Donepezil 1.5 $\mathrm{mg} / \mathrm{kg}$ (i.p) (Group III, IV and V respectively) showed significant $(p<0.001, p<0.001$ and $p<0.001$ for Group III, IV and $\mathrm{V}$ respectively) increase of Glutathione reductase level when compared with Group II animals. Results are plotted in histogram -9 .

\section{DISCUSSION}

The results from the behavior studies like open and closed field activities revealed the there was a significant improvement in memory and learning activity in animals after treatment with HAEAC at both the dose levels employed. The negative reinforcement on memory due to Beta amyloid protein was restored by the administration of the extract. This is evident from increased latency period in the shock avoidance paradigm. Further it was observed that spatial working memory (water maze) was enhanced by HAEAC, which emphasizes the positive effect of the extract on memory. A marked reduction in the enzyme level such as AchE, MAO activity was noticed in the brain samples of HAEAC treated animals, which was responsible for regeneration of acetylcholine (Ach) and Dopamine levels. Similar effect was observed in the animal treated with standard drug Donepezil. The antioxidants defense in the brain tissues were estimated in terms of SOD, GPx, GRD level by UV spectrophotometric method. From this study it was observed that there was a marked increase in SOD, GPX and GRD antioxidant enzyme levels in the extract treated groups. This clearly indicates the potential of the extract to delay the generation of free radicals, peroxy radicals leading to neuronal damage and memory impairment. It is also noticed that standard drug Donepezil has a potential role in restoring the antioxidant enzyme almost to the normal level.

\section{REFERENCES}

1. Puchchakayala G, Akina Sravanthi, Thati Mamatha. Neuroprotective Effects of Meloxicam and Selegiline in Scopolamine-Induced Cognitive Impairment and Oxidative Stress. Int J Alzheimers Dis 2012; 1: 1-8.

2. Satoskar RS, Nirmala NR, Bhandarkar SD. Pharmacology and pharmaco therapeutics. $22^{\text {nd }}$ edition. Mumbai: Popular Prakashan; 2011. p. 235-36.

3. Sharma HL, KK Sharma. Principles of pharmacology. $2^{\text {nd }}$ edition. Hyderabad: Paras Medical Publisher; 2011. p. 540-41.

4. Kiren Ubhi, Eliezer Masliah. Recent advances in the development of immunotherapies for tauopathies. Exp Neurol 2011; 230 Suppl 2: 157-61. http://dx.doi.org/10.1016/j.expneurol.2010.10.007 PMid: 20970422 PMCid:PMC3125641

5. John Aster, Abul K Abbas, Nelson Fausto, Vinay Kumar. Robbins and Cotran Pathologic Basis of Disease. $8^{\text {th }}$ edition. Elsevier; 2010. p. 1313-19.

6. David L Jones. Palms throughout the World. Australia: New Holland publishers; 1995.

7. Thomas SJ, Mac Lennan R. Slaked lime and betel nut cancer in Papua New Guinea. The Lancet Oncology 1992; 340 Suppl 8819. 577-78. http://dx.doi.org/10.1016/0140-6736(92)92109-S

8. Hemantha KA, Udaya SU, Newell WJ, Ratital L, Saman W. Betelquid chewing with or without tobacco is a major risk factor for oral potentially malignant disorders in Sri Lanka: A case-control study. J. Oral Oncology 2010; 46 Suppl 4: 297-301. http://dx.doi.org/ 10.1016/j.oraloncology.2010.01.017 PMid:20189448

9. The World Health Organization IARC Expert Group. IARC Monographs on the Evaluation of the Carcinogenic Risk of Chemicals to Humans, Tobacco Habits Other than Smoking; BetelQuid and Areca-nut Chewing; and Some Related Nitrosamines. [monograph on the Internet]. Lyon: IARC Press. Available from http://monographs.iarc.fr/ENG/Monographs/vol37/volume37.pdf; 1985.

10. Ines TK, Takeshi N, Hiroaki K, Hirotsugu M, Masao H, Tsuneo N et al. Screening of various plant extracts used in Ayurvedic medicine for inhibitory effects on human immunodeficiency virus type 1 (HIV-1) protease. Phytotherapy Research 1995; 9 Suppl 3: 180-184. http://dx.doi.org/10.1002/ptr.2650090305

11. Watoo P, Waraporn P, Hiroyuki T, Kanchalee J, Sakchai W, Kornkanok I. Comparison of various extraction method of Bacopa monnieri. Naresuan University Journal 2007; 15 Suppl 1: 29-34.

12. Raghavendra M, Rituparna M, Shafalika K, Acharya SB. Role of Ocimum sanctum in the experimental model of Alzheimer disease in rats. Int J green pharmacy 2009; 3 Suppl 1: 6-15.

13. Turner RA. Depressants of the central Nervous System. Screening procedure in Pharmacology. $1^{\text {st }}$ edition. New York: Academic press; 1972. p. 78-88.

14. Thakur VD, Mengi SA. Neuropharmacological profile of Eclipta alba linn. Hassk. J Enthopharmacol 2005; 102: 23-31. http://dx.doi.org/10.1016/j.jep.2005.05.037 PMid:16054316

15. Hanumanthachar Joshi, Milind Parle. Zingiber officinale: 
Evaluation of its nootropic effect in mice. Afr. J. Trad. Cam 2006; 3 Suppl 1: $64-74$.

16. Joshi H, Parle M. Nardostachys Jatamansi improves learning and memory in mice. J Med Food 2006; 9: 3-18. http://dx.doi.org /10.1089/jmf.2006.9.113 PMid: 16579738

17. Morris R. Development of a water maze procedure for studying spatial learning in the rat. J Neuroscience Methods 1984; 11: 47-60. http://dx.doi.org/10.1016/0165-0270(84)90007-4

18. Min Hye Yang, Kee Dong Yoon, Young Won Chin, Ju Hyun Park, Seung Hyun Kim, Jin Woong Kim. Neuroprotective effects of Dioscorea opposite on scopolamine induced memory impairement in vivo behavioral tests and in vitro assays. J Ethnopharmacol 2009; 121: 130-34. http://dx.doi.org/10.1016/j.jep.2008.10.010 PMid:190 07874

19. Vinutha B, Prashanth D, Salma K, Sreeja SL, Pratiti D, Padmaja R, Radhika S et al. Screening of selected Indian medicinal plants for acetylcholinesterase inhibitory activity. Journal of Ethnopharmacology 2007; 109: 359-63. http://dx.doi.org/10.1016/ j.jep.2006.06.014 PMid:16950584
20. Lowry OH, Rosenbrough NJ, Farr AL, Randall RJ. Protein measurement with the Folin phenol reagent. J. Biol. Chem 1951; 193: 265-75. PMid: 14907713

21. Rosa Resende, Paula Isabel Moreira, Teresa Proença, Atul Deshpande, Jorge Busciglio, Cláudia Pereira et al. Brain oxidative stress in a triple-transgenic mouse model of Alzheimer disease. Free Radical Biology and Medicine 2008; 44: 2051-057. http://dx. doi.org/10.1016/j.freeradbiomed.2008.03.012 PMid:18423383

22. Sapakal VD, Shikalgar TS, Ghadge RV, Adnaik RS, Naikwade NS, Magdum CS. In vivo screening of antioxidant profiles a review. Journal of Herbal Medicine and Toxicology 2008; 2 Suppl 2: 1-8.

\section{Cite this article as:}

R. Kannan, D. Sivaraman, P. Muralidharan, N. Deepakvenkataraman. Neuroprotective effect of hydroalcoholic extract of Areca catechu Linn on $\beta$-amyloid (25-35) induced cognitive dysfunction in mice. Int. J. Res. Ayurveda Pharm. 2013;4(5):747-753 http://dx.doi.org/10.7897/22774343.04525 